\title{
The study of controllability of motion of tractor aggregate of module type
}

\author{
Adamchuk V. ${ }^{1}$, Bulgakov V. ${ }^{2}$, Nadykto V. ${ }^{3}$, Holovach I. ${ }^{4}$, Prysiazhniuk D. ${ }^{5}$, Parakhin $0 .{ }^{6}$ \\ ${ }^{1} N S C$ «Institute of Mechanization and Electrification of Agriculture» \\ 11 Vokzalna Str., Hlevakha township, Vasylkiv district, Kyiv oblast, 08631, Ukraine \\ ${ }^{2,}{ }^{4}$ National University of Life and Environmental Sciences of Ukraine \\ 15 Heroiv Oborony Str., Kyiv, 03041, Ukraine \\ ${ }^{3,6}$ Tavria State Agrotechnological University named after Dmytro Motornyi \\ 18 B. Khmelnytskoho Ave., Melitopol, Zaporizhzhia oblast, 72312, Ukraine \\ ${ }^{5}$ Ladyzhyn College of Vinnytsia National Agrarian University \\ 5 Petra Kravchyka Str., Ladyzhyn, Vinnytsia oblast, 24321, Ukraine \\ e-mail: 1vvadamchuk@gmail.com, ${ }^{2} v$ bulgakov@meta.ua, ${ }^{3}$ volodymyr.nadykto@tsatu.edu.ua, \\ 4holovach.iv@gmail.com, ${ }^{5}$ m09049@meta.ua, ${ }^{6}$ oleksandr.parakhin@tsatu.edu.ua \\ ORCID: ${ }^{1} 0000-0003-0358-7946,{ }^{2} 0000-0003-3445-3721,{ }^{3} 0000-0002-1770-8297,{ }^{4} 0000-0003-1387-4789$, \\ ${ }^{5} 0000-0002-6369-5781,{ }^{6} 0000-0003-1972-3762$
}

Goal. To increase the level of controllability of motion of tractor aggregate (MTA) of modular type with the plow by equipping one of the hydro-cylinders, connecting energy and technological modules, with a special choke. Methods. Correlation and spectral analysis of output parameters of the dynamic system. Results. When driving MTA of module type with a plow on an agrotechnical background the control influence in the form of angle $\alpha$ of rotation of the steered wheels of the unit changed in a very narrow frequency range: $0 \ldots 2.0 \mathrm{~s}-1$, or $0 \ldots 0,32 \mathrm{~Hz}$. They fixed, although a positive but relatively weak, correlation between the parameters $\alpha$ and $\varphi$ (heading angle of power module) without throttling of the hydraulic cylinder of the technological module. The maximum value of the mutual correlation function of the connection between parameters $\alpha$ and $\varphi$ is shifted to the left of the zero ordinate for about $1 \mathrm{sec}$. Given this, the input dynamic system is not the angle $\alpha$, but its heading angle $\varphi$, which is undesirable for control. At the throttling of the hydraulic cylinder, the maximum of the estimated correlation function is shifted to the right from the zero ordinate. That means that the control action (angle $\alpha$ ) is the input and the heading angle $\varphi$ is the output of the considered dynamic system. In this case, the delay of the response of heading angle $\varphi$ on the change of control action $\alpha$ is approximately equal 0.51 , which is desirable for the improved control over MTA. Conclusions. Equipment of hydraulic cylinder of the modular power means with the throttle with the coefficient of resistance at the level of $1,03 \times 106 \cdot \mathrm{N} \cdot \mathrm{m} \cdot \mathrm{s} \cdot \mathrm{rad}-1$ allows: to increase the maximum value of the mutual correlation function between the control effect, i.e. the angle $\alpha$ of rotation of the steered wheels of the power module and its directional angle $\varphi$ to the level of 0.89 ; to shift the maximum value of that function to the right of the zero ordinate, providing the steering angle $\alpha$ of the steered wheels of the power module the role of the input (not output) influence; almost to halve the response lag of the heading angle $\varphi$ of the power module by changing the angle $\alpha$ of rotation of its driven wheels.

Key words: modular power tool, spectral density, normalized correlation function, throttling the hydraulic cylinder, the spectral density.

DOI: https://doi.org/10.31073/agrovisnyk202006-06

One of the most perspective directions in the development of tractor construction and use of machine and tractor units is their modular construction. In this variant, the traction unit consists of a energy unit (tractor) and a technological module. Their combination in one design is a machine and tractor unit of modular type (actually modular energy unit). A general view of such a unit with a five-hulled plough aimed at the rear of the technological module is shown in Fig. 1.

The energy module of such a machine and tractor unit is a tractor, the energy saturation of which should be higher $14 \mathrm{~kW} \cdot \mathrm{t}^{-1}$. But, as experience shows, in real-world conditions, the efficiency of using a modular power unit can be satisfactory even with less energy saturation of the tractor. 


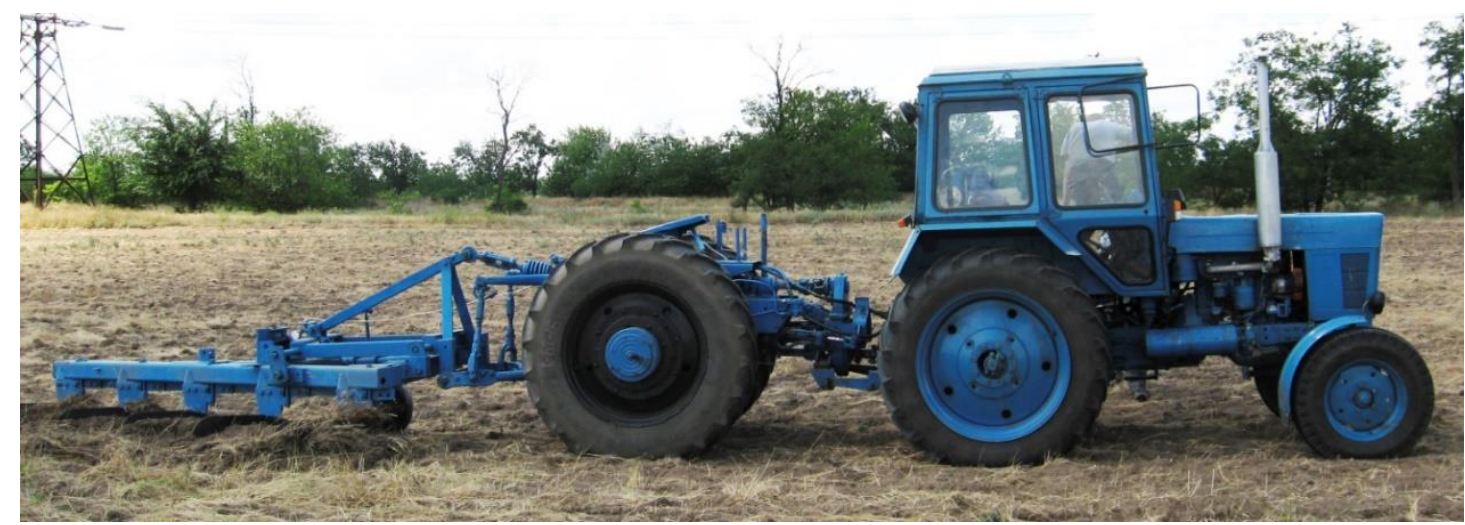

Fig. 1. Machine and tractor unit of the modular type with a five-hulled plough

The technological module of this machine and tractor unit is a separate bridge, whose wheels are driven from the synchronous power take-off shaft of the energy module (tractor). At the front of the technological module has a coupling device by means of which it is connected to the rear-mounted mechanism of the energy module, ie tractor. Coordination of circular linear speeds of the technological module wheels and rear wheels of the power module is carried out by means of the special reducer located on a frame of the technological module.

For coupling with agricultural implements, the technological module is equipped with a hydraulic attachment system, its own PTO shaft, a fifth wheel and a brake system.

The horizontal construction has an energy module for a technological module construction with vertical hinge. Its presence ensures the rotation of the technological module relative to the energy module by $\pm 30^{\circ}$ when the modular energy unit is moving on the return lane.

In the longitudinal-vertical plane, the energy module is connected to the technological module by a horizontal hinge. Thanks to it, the machine and tractor unit of the modular type can perform satisfactory copying of the longitudinal field profile.

Limited return of the energy module in the horizontal plane is provided by two hydraulic cylinders connecting the frames of the energy module and the technology module.

For oil flow from the overpiston cavity of the hydraulic cylinder into the underpiston cavity, they (cavities) are connected to each other by a hydraulic hose. However, during the testing of the modular energy unit it was found that when it moves as part of the unit on the return line, the technological module may have excessive fluctuations in the horizontal plane. As a consequence, there was a need to reduce the speed of the modular energy facility on the return field lane. And this, as we know, leads to a decrease in the productivity of the machine and tractor unit. So, increasing the controllability of a machine and tractor unit motion of modular type, consisting of an energy module (tractor) and an additional technological module is an actual scientific and technical problem.

Therefore, in order to reduce the fluctuations of the technological module in the horizontal plane and, consequently, to increase the controllability of the modular energy unit (tractor), in the hydraulic hose of one of the hydraulic cylinders connecting the energy and technological module, a throttle with a coefficient of resistance $\mathrm{K}_{\mathrm{m}}=1.03 \times 10^{6} \cdot \mathrm{N} \cdot \mathrm{m} \cdot \mathrm{s} \cdot \mathrm{rad}^{-1}$ was installed. Fig. 2 shows the connection scheme of the energy (tractor) and technological modules, which shows the installation in one of the hydraulic cylinders of the mentioned throttle.

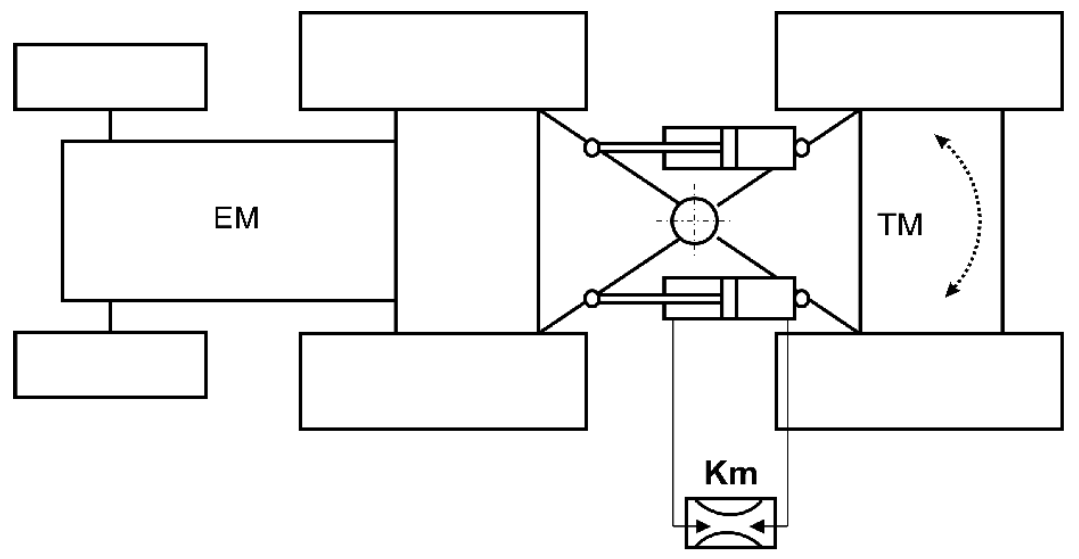

Fig. 2. Installation diagram of the throttle in the hydraulic cylinder connecting the energy and technological modules: EM - energy module; TM - technological module; $K_{m}$ - throttle, which creates a resistance coefficient 
Justification of the value of this coefficient based on data obtained from field experimental studies and is the subject of research in this article.

Analysis of research and publications. Traffic controllability of machine and tractor units of modern technical level is a significant problem in the field of agricultural mechanization. Therefore, the development of conditions and technical devices ensuring controlled movement of machine and tractor units, especially arable and tilled ones, is based on scientific research and engineering developments aimed mainly at ensuring the straightness of the movement trajectory and minimizing the "side tracking", etc. These issues are particularly acute for machine and tractor units built on a modular principle. In the scientific literature questions of controllability of movement of agricultural machine-and-tractor units are given many questions [1-11], especially at theoretical research of planeparallel movement of units [3-5].

Theoretical studies of motion controllability of machine and tractor units are based on fundamental studies, which are outlined in [12-19].

However, thorough controllability researches of movement of machine-and-tractor units of modular type at their movement on turn lanes and at transport crossings are not sanctified enough now in the literature.

The purpose of the research - to increase the controllability level of movement of the machine and tractor unit of modular type with a mounted plough by equipping one of the hydraulic cylinders connecting the power and process modules with a special throttle and scientific substantiation of the degree of its influence on the controllability of the mentioned unit.

Materials and methods of research. Experimental research of the machine and tractor unit of modular type with a mounted plough was carried out in the field on stubble after its flaking after winter wheat.

Technical characteristics of the machine and tractor unit of modular type are presented in the table.

Technical characteristics of the machine and tractor unit of modular type

\begin{tabular}{|l|c|}
\hline Energy module (tractor): & $3900(3.9)$ \\
Weight in working condition [kg (tonne)] & 77.2 \\
Motor power [kW] & 19.8 \\
Energy saturation rate [kW · ton-1] & 1500 \\
Front wheel track [mm] & 1500 \\
Rear wheel track [mm] & $13.6 \mathrm{R} 20$ \\
Front wheel tyre size & $15.5 \mathrm{R} 38$ \\
Rear wheel size & \\
Technological module: & 2600 \\
Weight in working condition [kg] & 1500 \\
Track size [mm] & $16.9 \mathrm{R} 38$ \\
Tyre size & \\
\hline
\end{tabular}

Thus preliminary before carrying out field experimental researches humidity and density of soil in layer $0 \ldots 10 \mathrm{~cm}$ was measured, and also amplitude and frequency of fluctuations of unevenness of a field along future movement of the given machine-tractor unit.

Movement of this arable unit on the return lane was carried out in the same gear with an installed throttle $\left(K_{m}=1.03 \times 10^{6} \cdot \mathrm{N} \cdot \mathrm{m} \cdot \mathrm{s} \cdot \mathrm{rad}^{-1}\right)$ in and out of a hydraulic cylinder $\left(\mathrm{K}_{\mathrm{m}}=0\right)$. The travel path of the unit was $50 \mathrm{~m}$. Based on the fact that the machine was moving evenly, the speed $V_{a}$ of his movement was determined by this expression:

$$
V_{a}=50 \cdot t^{-1}
$$

where $t$ - the time of the unit's passage of a $50 \mathrm{~m}$ long section.

To record the travel time of a mobile machine and tractor unit of the modular type with a plough on the return lane, an electronic stopwatch with the accuracy of the measurement $\pm 0.1 \mathrm{~s}$ was used.

In the movement process of the machine and tractor unit of modular type with the help of special equipment the rotation angle $\alpha$ of controlled wheels of the power module (tractor) and its course angle $\varphi$ were registered.

To measure soil moisture $W$ the electronic measuring device MG-44 (Ukraine) was used with the accuracy of measurement $\pm 1 \%$. Measurement of soil density $\rho_{q}$ were carried out by our developed device according to the method [5]. The number of measurements of each parameter $W$ and $\rho_{q}$ was no less 50.

The angle $\alpha$ of rotation of the controlled wheels of the energy module of the modular energy unit was recorded using an SP-3A resistor with a linear characteristic and rating of $470 \mathrm{Ohm}$. The resistor was mounted on the rotation axis of the left front wheel of the energy module.

To measure fluctuations in the longitudinal profile of the field, a special registration device was used, the element of which was an SP-3A resistor with a linear characteristic and a nominal value of 470 ohms.

The course angle $\varphi$ of the energy module of the machine and tractor unit of modular type was recorded with a GY-521 gyroscope with the Arduino device (China). 
Electrical signals from the gyroscope and resistors to record the angle $\varphi$, as well as fluctuations in the longitudinal profile of the field were fed to an analog-to-digital converter (Ukraine) and then to a PC. The measurement repeatability of these parameters is 3 .

The following statistical characteristics, such as dispersions, as well as normalized correlation functions and spectral densities, were calculated from the data sets obtained in this case.

For the analysis of movement controllability of the machine and tractor unit of modular type with a plough at various values of throttling of the hydraulic cylinder the normalized mutual correlation function connecting fluctuations of an angle $\alpha$ of rotation of operated wheels of the power module with fluctuations of its rate angle $\varphi$ was used.

Research results. At carrying out of experimental researches of the machine-tractor unit movement of modular type with a hinged plough on a return strip average value of humidity of soil of a field in a layer $0 . . .10 \mathrm{~cm}$ was equal to $15.3 \%$.Density of soil in the same layer did not exceed $1.24 \mathrm{gr} \cdot \mathrm{sm}^{-3}$.

The average speed for this modular arable machine and tractor unit on the return lane was $2.4 \mathrm{~m} \cdot \mathrm{s}^{-1}$.

The analysis of the data characterizing the fluctuations of the longitudinal field profile showed the following. The length of the correlation relation of the normalized correlation function of this process is $1 \mathrm{~m}$ (Fig. 3).

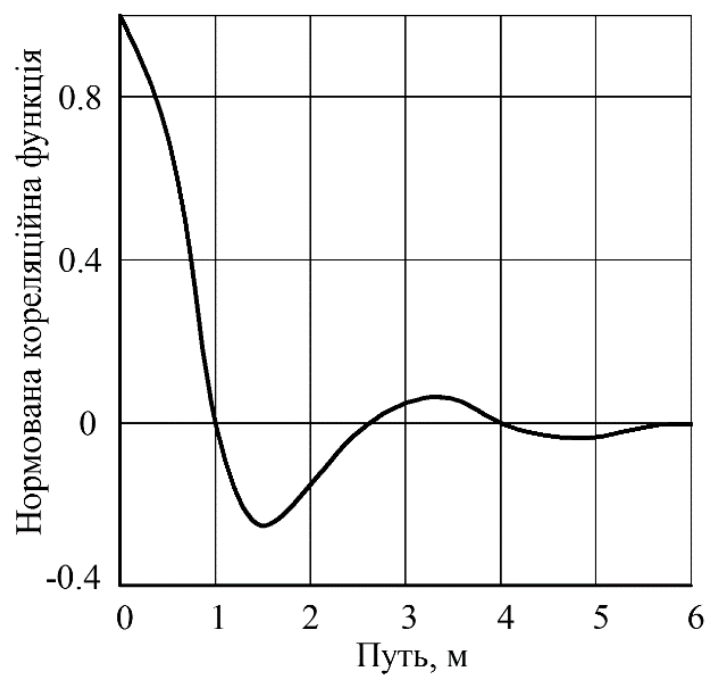

Fig. 3. normalized correlation function of fluctuations in the longitudinal field profile

By knowing the speed of the machine, you can easily determine the time of the correlation link. In this case, at the speed of this machine $2.4 \mathrm{~m} \cdot \mathrm{s}^{-1}$ it is equal: $1 \cdot(2.4)^{-1}=0.42 \mathrm{~s}$. It can be said that oscillations of the longitudinal field profile have almost no hidden periodic component. The information about changes in the correlation function, which takes place in Fig. 3, is not enough to determine the source of their generation.

The dispersion of oscillations of the process under consideration is equal to $0.91 \mathrm{sm}^{2}$. Mostly it is concentrated in a fairly narrow range of frequencies $0 \ldots 2 \mathrm{~m}^{-1}$ (Fig. 4). Taking into account the speed of this machine and tractor unit $2.4 \mathrm{~m} \cdot \mathrm{s}^{-1}$ this range is equal to $0 \ldots 4.8 \mathrm{~s}^{-1}$ or $0 \ldots 0,76 \mathrm{~Hz}$.

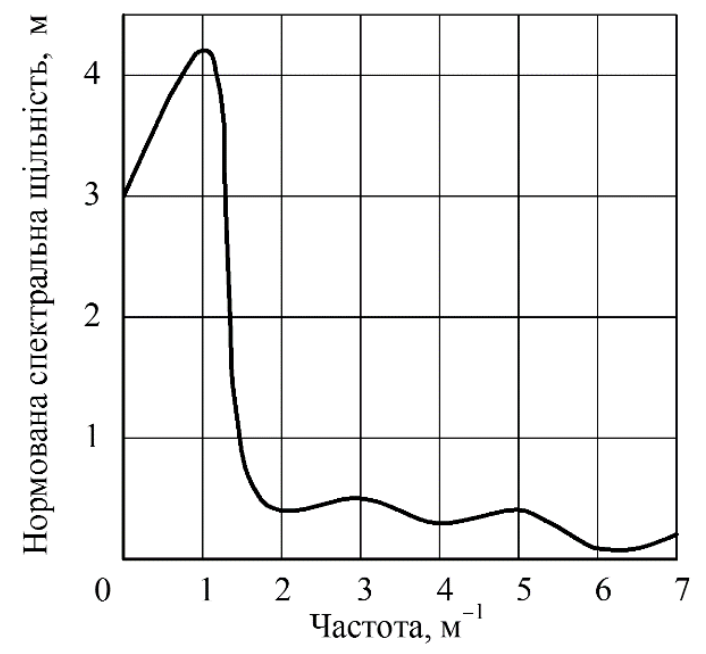

Fig. 4. Spectral density of vibrations of the longitudinal field profile 
The frequency of the spectral density cut, as can be seen from the data in Fig. 4, practically does not exceed $6 \mathrm{~m}^{-1}$ or $14.4 \mathrm{~s}^{-1}$, which is equal to $2,3 \mathrm{~Hz}$.

When the unit was moving on an agronomic background with such characteristics of longitudinal profile oscillations, the control action in the form of rotation angle $\alpha$ of the controlled wheels of the modular energy unit was changed in a very narrow range. Thus, the main part of the dispersion of vibrations of this parameter is concentrated in the frequency range of $0 \ldots 2.0 \mathrm{~s}^{-1}$ or $0 \ldots 0.32 \mathrm{~Hz}$ (Fig. 5).

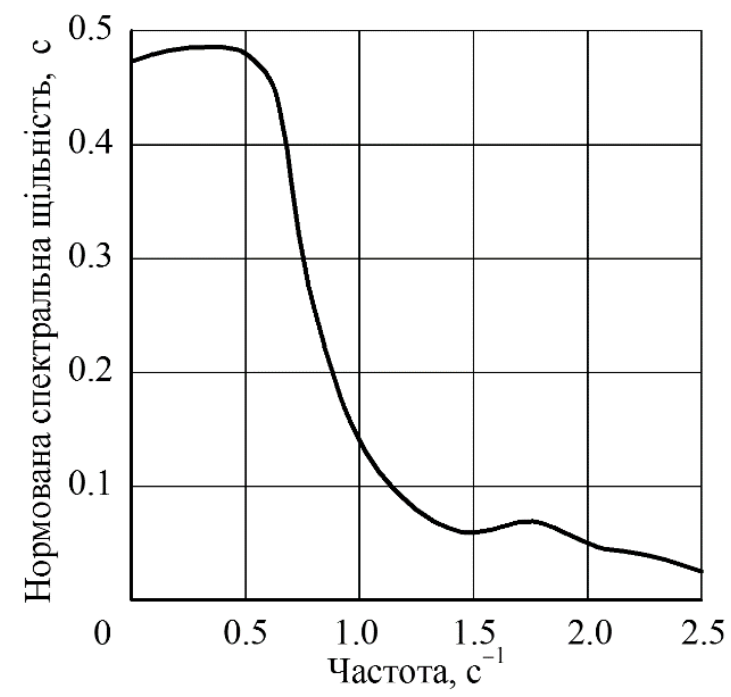

Fig. 5. Normalized spectral density of oscillations of the rotation angle $\alpha$ of the modular energy unit controlled wheels

The maximum value of the normalized spectral density of oscillations of the angle $\alpha$ falls on a rather narrow frequency range: $0.30 \ldots 0.35 \mathrm{~s}^{-1}$. All this points to the desired low-frequency nature of the changes in the manipulated value in question.

As it turned out, the block-module unit worked out the fluctuations of the input effect differently. In the absence of throttling of the hydraulic cylinder of the technological module of the modular energy unit between the parameters $\alpha$ and $\varphi$ a positive correlation relation was revealed. But, firstly, it is weak enough as the maximum value of the mutual correlation function does not exceed the estimate of 0.34 (curve 2, Fig. 6).

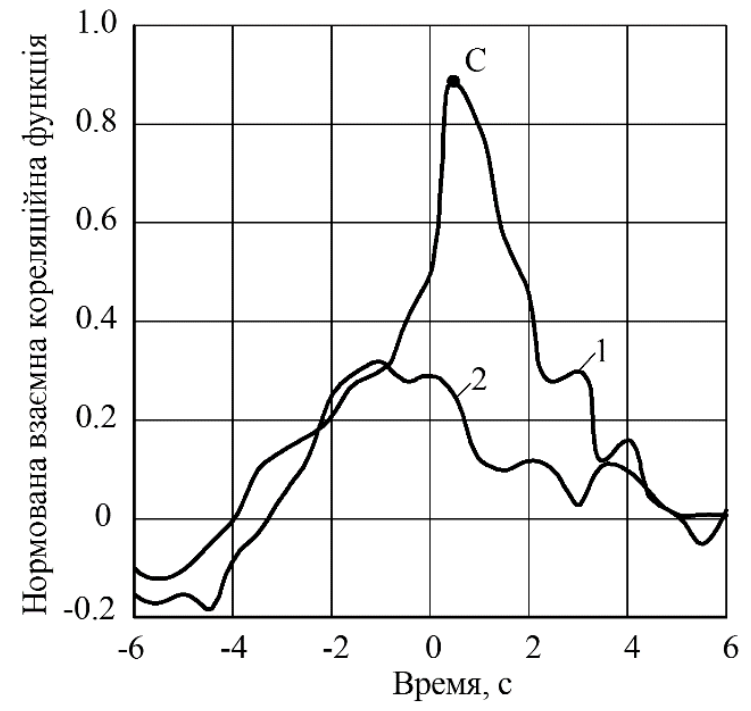

Fig. 6. Normalized mutual correlation functions of oscillations of the course angle $\varphi$ caused by oscillations of the angle $\alpha$ at different levels of throttling of the hydraulic cylinder of the technological module: $1-K_{m}=1.03 \times 10^{6} \cdot \mathrm{N} \cdot \mathrm{m} \cdot \mathrm{s} \cdot \mathrm{rad}^{-1} ; 2-K_{m}=0$

Secondly, the maximum value of this function is shifted to the left of the zero coordinate by about $1 \mathrm{~s}$. This means that the input of this dynamic system is not the angle $\alpha$ of rotation of the controlled wheels of the energy module, but its course angle $\varphi$. That is, that the control action $\alpha$ is a reaction to the change of the heading angle $\varphi$ with time delay at $1 \mathrm{~s}$. 
The reason for changing the course angle $\varphi$ of the modular energy unit in this case may be variations of the turning moment acting on the side of the technological module, or some other disturbances.

At the same time, the introduction of the hydraulic damper in the hydraulic cylinder of the technological module of the modular energy unit with a resistance coefficient $K_{\mathrm{m}}=1.03 \times 10^{6} \cdot \mathrm{N} \cdot \mathrm{m} \cdot \mathrm{s} \cdot \mathrm{rad}^{-1}$ principally changes the behavior of the mutual correlation function $\alpha-\varphi$. Moreover, both qualitatively and quantitatively (curve 1, Fig. 6).

First, the force of correlation between changes in $\alpha$ and $\varphi$ increases sharply. In comparison with the variant $\mathrm{K}_{\mathrm{m}}=0$ the maximum of the mutual correlation function increases by 2.6 times, reaching the score of 0.89 .

Secondly, the maximum of the evaluated function (curve 1, Fig. 6) is shifted to the right from the zero coordinate. This means that the control action (i.e. angle $\alpha$ ) is the input, and the exchange rate angle $\varphi$ of the modular energy facility is the output of the considered dynamic system.

Thirdly, the latency of the reaction of the course angle $\varphi$ to the change of the control action $\alpha$ of the wheels of the energy module of the modular energy unit is almost reduced by half. In this case it is approximately equal to $0.51 \mathrm{~s}$. Such a result is desirable, because the reaction of the dynamic system under consideration to the change of the control action should ideally be momentary. So it must be done with zero delay. But as it is impossible to reach it in practice, any constructive and technological solution aimed at reduction of reaction of a dynamic system to an input useful signal is desirable. In our case, such a solution is the installation of a throttle in the hydraulic cylinder of the technological module of the modular energy unit.

\section{Conclusions}

To increase movement controllability of the machine and tractor unit of modular type consisting of energy and technological modules, it is possible by throttling of one of hydraulic cylinders which limit mutual return of these modules among themselves in a horizontal plane.

Equipping the hydraulic cylinder of the modular energy unit with a choke with resistance coefficient at the level of $1,03 \times 10^{6} \mathrm{~N} \mathrm{~m} \mathrm{sad}{ }^{-1}$ allows:

- to bring the maximum value of the mutual correlation function between the control action, i.e. the angle $\alpha$ of rotation of the controlled wheels of the energy module of the modular energy unit, and its exchange rate angle $\varphi$ to the level 0.89;

- shift the maximum value of the given mutual correlation function to the right of the zero coordinate, thus providing the angle $\alpha$ of rotation of the controlled wheels of the energy module the role of the input (not the initial) influence;

- to reduce by almost half the delay of the response of the course angle $\varphi$ of the energy module to the change of the angle $\alpha$ of its controlled wheels.

\section{References}

1. Bulgakov, V., Ivanovs, S., Nadykto, V., Kuvachov, V., \& Masalabov, V. (2018). Research on the turning ability of a two-machine aggregate. INMATEH - Agric. Eng., 54, 139-146.

2. Padureanu, V., Lupu, M.I., \& Canja, C. M. (2013). Theoretical research to improve traction performance of wheeled tractors by using a suplementary driven axle, in: Computational Mechanics and Virtual Engineering. Brasov, Romania. (pp. 410-415).

3. Kasymov, A. Sh., \& Zolotarev, V. V. (1988). Ustanovivsheesya pryamolineynoe dvizhenie pakhotnogo agregata s peredney i zadney naveskoy [The steady linear motion of the arable unit with the front and rear link]. Tractors and agricultural machines, 1, 34-38. [In Russian].

4. Stasilevich, A. G. (2013). Upravlyaemost kolesnogo traktora s naveskami selskokhozyaystvennykh mashin [Controllability of a wheeled tractor with attachments of agricultural machines]. Bulletin of the Belarussian-Russian University, 4, 95-100. [In Russian].

5. Nadykto, V. T. (2016). Otsinka kerovanosti rukhu mashynno-traktornykh ahrehativ [Evaluation of the controllability of the movement of machine-tractor units]. Machinery and technologies of agro-industrial complex, 2, 10-14. [In Ukrainian].

6. Fomin, S. D. (2011). Ustoychivost upravlyaemogo dvizheniya MTA s razlichnym tipom kinematicheskoy svyazi vedushchikh koles [The stability of the controlled movement of the MTA with a different type of kinematic connection of the driving wheels]. Bulletin of the Lower Volga Agricultural University, 4, 1-7. [In Russian].

7. Tajanowskij G., \& Tanas W. (2012). Analysis of movement kinematics at turn of wheel tractor with semitrailer with articulated operated draught bar. Journal of Research and Applications in Agricultural Engineering, 57(2), 190-196.

8. Lebedev A.T., Artyomov M. P., \& Shulyak M. L. (2015). Zabezpechennia stiikosti i kerovanosti silskohospodarskykh ahrehativ iz zminnoiu masoiu [Ensuring the stability and controllability of variable weight agricultural units]. Proceedings of the Vinnytsia National Agrarian University, 1(89), 57-61. [In Ukrainian].

9. Bondar, A. M. (2009). Faktory polipshennia kerovanosti MTA [Factors for improving the controllability of MTU]. Bulletin of the Dnipropetrovsk State Agrarian University, 2, 268-270. [In Ukrainian].

10. Chorna, T. S. (2016). Analiz sposobiv otsiniuvannia stiikosti ta kerovanosti robochoho rukhu posivnykh ahrehativ [Analysis of methods of estimation of stability and controllability of working movement of sowing units]. Scientific Bulletin of the Tavriya State Agrotechnological University, 3, 224-232. [In Ukrainian]. 
11. Artyomov, M. P. (2011). Doslidzhennia kryteriiv kerovanosti mobilnykh silskohospodarskykh mashyn [Research criteria for controllability of mobile agricultural machines]. Construction, production, and operation of agricultural machines, 1(41), 265-271. [In Ukrainian].

12. Priporov, Ye. V. (2015). Povyshenie prodolnoy ustoychivosti navesnykh agregatov [Increased longitudinal stability of mounted units]. Agricultural Innovation, 5(15), 115-119. [In Russian].

13. Vasilev, A. O., Andreev, R. V., \& Grigorev, A. O. (2018). Vliyanie parametrov opornykh koles na velichinu otkloneniya pritsepnoy mashiny ot kursa sledovaniya [The influence of the parameters of the support wheels on the deviation of the trailed machine from the course]. Agrarian Bulletin of the Upper Volga, 1(22), 55-59. [In Russian].

14. Zhileykin, M. M., \& Shinkarenko, V. A. (2015). Kachestvennyy analiz metodov povysheniya upravlyaemosti i ustoychivosti kolesnykh mashin [Qualitative analysis of methods to improve manageability and the stability of wheeled vehicles]. News of higher educational institutions. Mechanical engineering, 1(658), 42-48. doi: 18698/0536-1044-2015-1-42-48. [In Russian].

15. Kupryashkin, V. F., Naumkin, N. I., \& Kupryashkin, V. V. (2017). Issledovanie ustoychivosti dvizheniya podvizhnogo modulya eksperimentalnoy ustanovki pri ispytanii aktivnykh rotatsionnykh rabochikh organov pochvoobrabatyvayushchikh mashin [The study of the stability of movement of a movable module of an experimental setup when testing active rotary working bodies of tillage machines]. Bulletin of the Mordovian University, 26(2), 246-258. doi: 10.15507/0236-2910.026.201602.246-258. [In Russian].

16. Zalypaka, V. D. (2015). Sposib zbilshennia pozdovzhnoi stiikosti korotkobazovykh kolisnykh mashyn ta yoho matematychnyi analiz koordynatnym metodom [The method of increasing the longitudinal stability of shortbase wheeled machines and its mathematical coordinate analysis method]. Weapons systems and military equipment, 3(43), 81-84. [In Ukrainian].

17. Borodin, I. F., \& Kirilin, N. I. (1977). Osnovy avtomatiki i avtomatizatsii proizvodstvennykh protsessov [Fundamentals of automation and automation of production processes]. Moscow: Kolos. [In Russian].

18. Solodovnikov V. V., Plotnikov V. N., \& Yakovlev, A. V. (1985). Osnovy teorii i elementov sistem avtomaticheskogo regulirovaniya [Fundamentals of the theory and elements of automatic control systems]. Moscow: Mechanical engineering. [In Russian].

19. Bulgakov, V., Pascuzzi, S., Santoro, F., \& Anifantis, A. S. (2018). Mathematical model of the plane-parallel movement of the self-propelled root-harvesting machine. Sustainability, 10, 3614. Switzerland. (pp. 1-11). doi: 10.3390/su10103614. 